\title{
ШЛЯХИ ПІДВИЩЕННЯ ЕФЕКТИВНОСТІ Й ТЕРМІНУ ЕКСПЛУАТАЦЇ̈ ФОТОЕЛЕКТРИЧНИХ МОДУЛІВ І ФОТОЕЛЕКТРИЧНИХ СТАНЦІЙ
}

\author{
В.О. Пундсв, В.І. Шевчук, І.О. Шейко \\ Інститут відновлюваної енергетики НАН України, \\ 02094, вул. Гната Хоткевича, 20А, м. Київ, Україна.
}

Кожна складна енергетична система, до яких можна також віднести й фотоелектричні станиї (ФЕС), впродовж всього терміну експлуатації, починаючи від будівництва і до його закінчення, піддаються дії різноманітних чинників, які впливають як на сам термін експлуатації станиії, так і на ефективність ї̈ роботи.

Зниження ефективності (ККД) та скорочення терміну експлуатації фотоелектричних станцій залежить від впливу кліматичних умов (коливань температури навколишнього середовища, атмосферних опадів тощо) в районі розташування станції, від незворотних фізичних прочесів, що відбуваються в елементах конструкиї ФЕС та ї̈ основних вузлах, від якості виготовлення окремих складових станщії, від людського фактора - некваліфікованого обслугового персоналу. Деякі 3 вищеперерахованих факторів впливу на роботу ФЕС можна об'єднати в окрему групу під загальним терміном - старіння, або деградачія. Найбільше часова деградачія позначається на основній складовій кожної ФЕС - фотоелектричних модулях (ФЕМ).

Автори в иій публікаиії поставили собі за мету виявити, систематизувати за різними критеріями та дослідити найбільш масові й типові види деградації ФЕМ, які зазвичай мають місие. Проведено аналіз та теоретичне обтрунтування причин їх появи, наслідків та шляхів подолання, а також шляхів запобігання їм.

Крім того, в роботі пропонуються варіанти розв 'язання визначених проблем окремих видів виходу з ладу ФЕМ шляхом зміни й удосконалення схемних та конструктивно-технологічних рішень за умови проєктування ФЕС $i$ також варіанти доопрацювання ФЕМ, щзо входять до складу ФЕС.

Рімення, щуо пропонуються, дозволять підвищити ефективність і надійність експлуатаиії ФЕМ та ФЕС в иүілому.

Бібл. 10, рис. 5.

Ключові слова: деградація, фотоелектрична станція, фотоелектричний модуль, комбінований фотоелектричний модуль.

\section{WAYSTOINCREASE THE EFFICIENCY AND SERVICE LIFE OF PHOTOVOLTAIC MODULES AND PHOTOVOLTAIC PLANTS}

\author{
V. Pundiev, V. Shevchuk, I. Sheiko \\ Institute of Renewable Energy of the National Academy of Sciences of Ukraine, \\ 02094, 20A HnataKhotkevycha St., Kyiv, Ukraine.
}

Each complex power system, which can also include photovoltaic plants (PVP), during the entire period of operation, from construction to its completion, are exposed to various factors and factors that affect the service life of the station and and the effectiveness of its work.

Reduced efficiency (efficiency) and reduced service life of photovoltaic plants depends on the influence of climatic conditions (fluctuations in ambient temperature, precipitation etc.) in the area of the station, on irreversible physical processes occurring in the structural elements of the PVP and its main components, the quality of manufacture individual components of the station, from the human factor - the negative effects of unqualified service personnel. Some of the above factors influencing the work of PVP can be combined into a separate group under the general term - aging, or as -degradation. The greatest temporal degradation affects the main component of each PVP-photovoltaic modules (PVM).

The authors of this publication aim to identify, systematize by various criteria and investigate the most common and typical types of degradation of PVM, which usually occur, with analysis and theoretical justification of their causes, consequences and ways to overcome or prevent.

In addition, the paper offers options for solving certain problems of certain types of failure of photovoltaic modules by changing and improving circuit and design solutions for the design of photovoltaic stations and also options for refining photovoltaic modules that are part of photovoltaic stations.

The proposed solutions will increase the efficiency and reliability of photovoltaic modules and photovoltaic stations in general.

Ref. 10,fig. 5 .

Keywords: degradation, photovoltaic station, photovoltaic module, combined photovoltaic module. 


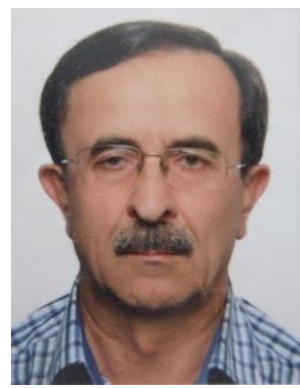

B.О. Пундєв V. Pundiev

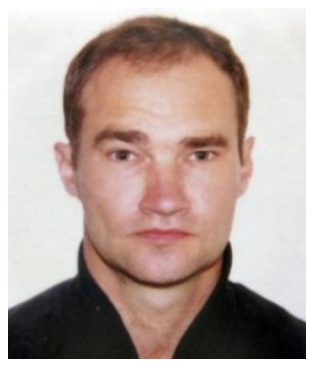

B.I. Шевчук V. Shevchuk

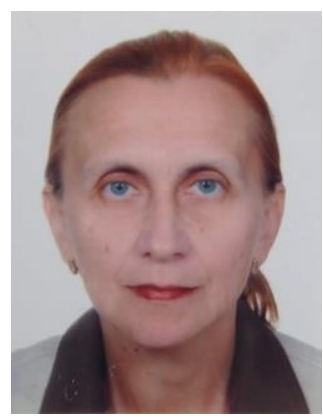

I.O. Шейко I. Sheiko
Відомості про автора: науковий співробітник відділу сонячної енергетики Інституту відновлюваної енергетики НАН України

Освіта: Ворошиловградський машинобудівельний інститут, факультет електромашинобудування; спеціальність «Електричні машини та апарати»

Наукова сфера: відновлювана енергетика, зокрема сонячна енергетика

Публікації: 26

ORCID: 0000-0003-3750-8812

Контакти: тел.: +38(044)206-28-09

e-mail: renewable@ukr.net

Відомості про автора: науковий співробітник відділу сонячної енергетики Інституту відновлюваної енергетики НАН України

Освіта: Київський політехнічний інститут, електротехнічний факультет; спеціальність «Електричні станції»

Наукова сфера: відновлювана енергетика, зокрема сонячна фотоенергетика

Публікації: 41

ORCID: 0000-0002-4176-7799

Контакти: тел.: +38 (044) 206-28-09

e-mail:renewable@ukr.net

Відомості про автора: провідний інженер відділу сонячної енергетики Інституту відновлюваної енергетики НАН України Освіта: Київський політехнічний інститут, факультет автоматики та приладобудування; спеціальність «Електронні обчислювальні машини»

Наукова сфера: відновлювана енергетика, зокрема сонячна енергетика

Публікації: 5

ORCID: 0000-0002-5770-3677

Контакти: тел.: +38(044)206-28-09

e-mail:renewable@ukr.net
Author information: Research Associate of Solar Power Engineering Department of Institute of Renewable Energy at NAS of Ukraine Education: The Voroshilovgrad MachineBuilding Institute in Electrical Machines and Devices

Research area: renewable power in particular solar power

Publications: 26

ORCID: 0000-0003-3750-8812

Contacts: tel.: +38(044)206-28-09

e-mail: renewable@ukr.net

Author information: Research Associate of Solar Power Engineering Department of Institute of Renewable Energy at NAS of Ukraine

Education: The Kyiv Polytechnic Institute in

Power Plants

Research area: renewable power, in particular photovoltaics

Publications: 41

ORCID: 0000-0002-4176-7799

Contacts: tel.: +38(044)206-28-09

e-mail: renewable@ukr.net

Author information: leading associate of Solar Power Engineering Department of Institute of Renewable Energy at NAS of Ukraine

Education: Kiev Polytechnic Institute, Faculty of Automation and Electrical Equipment, specialty - electronic machined

Faculty of Automation and Instrumentation, specialty - electronic computers

Research area: renewable power in particular solar power

Publications: 5

ORCID: 0000-0002-5770-3677

Contacts: tel.: +38(044)206-28-09

e-mail:renewable@ukr.net
Вступ. На тлі ростучого дефіциту органічних енергоносіїв та їх подорожчання стрімко зростає частка електроенергії, виробленої за допомогою відновлюваних джерел енергії. Цей невпинний процес повною мірою стосується i сонячної енергетики, зокрема фотоенергетики. Водночас із ростом об'ємів введених потужностей фотоенергетики та збільшенням термінів експлуатації вже діючих ФЕС дедалі частішими стають випадки виходу з ладу ФЕМ - основної складової ФЕС та інших вузлів станцій, накопичуються статистичні дані щодо випадків відмов та виходу з ладу тих або інших основних складових ФЕС. Деякі з цих випадків вже мають навіть системний характер. I тому вже назріла нагальна потреба в їх аналізі та пошуку шляхів зменшення й подолання наслідків деградації i, відповідно, підвищення ефективності та подовження терміну експлуатації ФЕС.

Постановка завдання. Як показує практика довготривалої експлуатації ФЕМ у складі ФЕС, в модулях відбуваються такі основні деградаційні процеси:

а) деламінування (відшарування ламінату від поверхні сонячних елементів);

б) втрата прозорості ламінату під комбінованою дією різних кліматичних факторів;

в) корозія сонячних елементів;

г) механічне пошкодження сонячних елементів із втратою ними працездатності; 
д) механічне пошкодження й порушення (його пошкодження) за час тривалої експлуатації; нормальної роботи розподільних коробок;

е) пошкодження зовнішніх з'єднань і вихід 3 ладу блокувальних і байпасних діодів;

ж) місцевий перегрів за умови поганого що пов'язана 3 монтажем (пошкодження розподільної коробки, роз'ємних з'єднань, пошкодження прозорого покриття, пошкодження електричного контакту в паяних та механічних рамного корпуса тощо). з'єднаннях;

Яскравий приклад наслідків дії

з) деградація верхнього прозорого покриття деградаційних змін в ФЕМ показано на рис. 1.

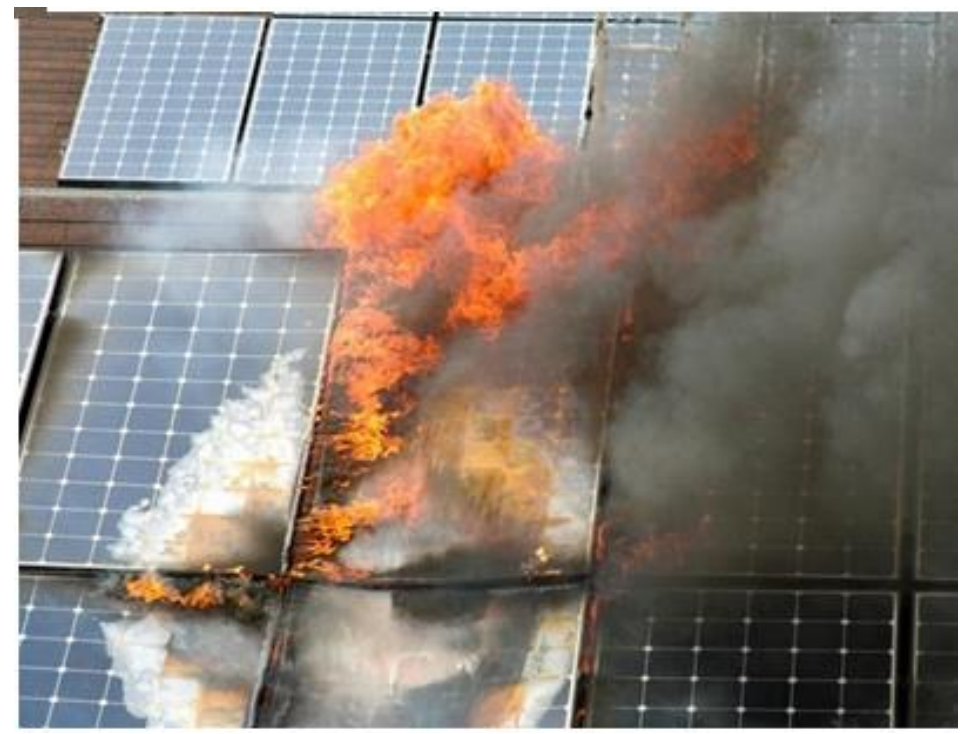

Рис. 1. Приклад дії деградаційних змін у фотоелектричних модулях ФЕС

Fig. 1. Example of degradation changes in photovoltaic modules of PVP

Виклад основного матеріалу. За загальної кількості відмов за умови тривалої накопиченими статистичними даними основні види експлуатації у складі ФЕС показано на рис. 2 [4]. деградації ФЕМ та їх частки (в процентах) від

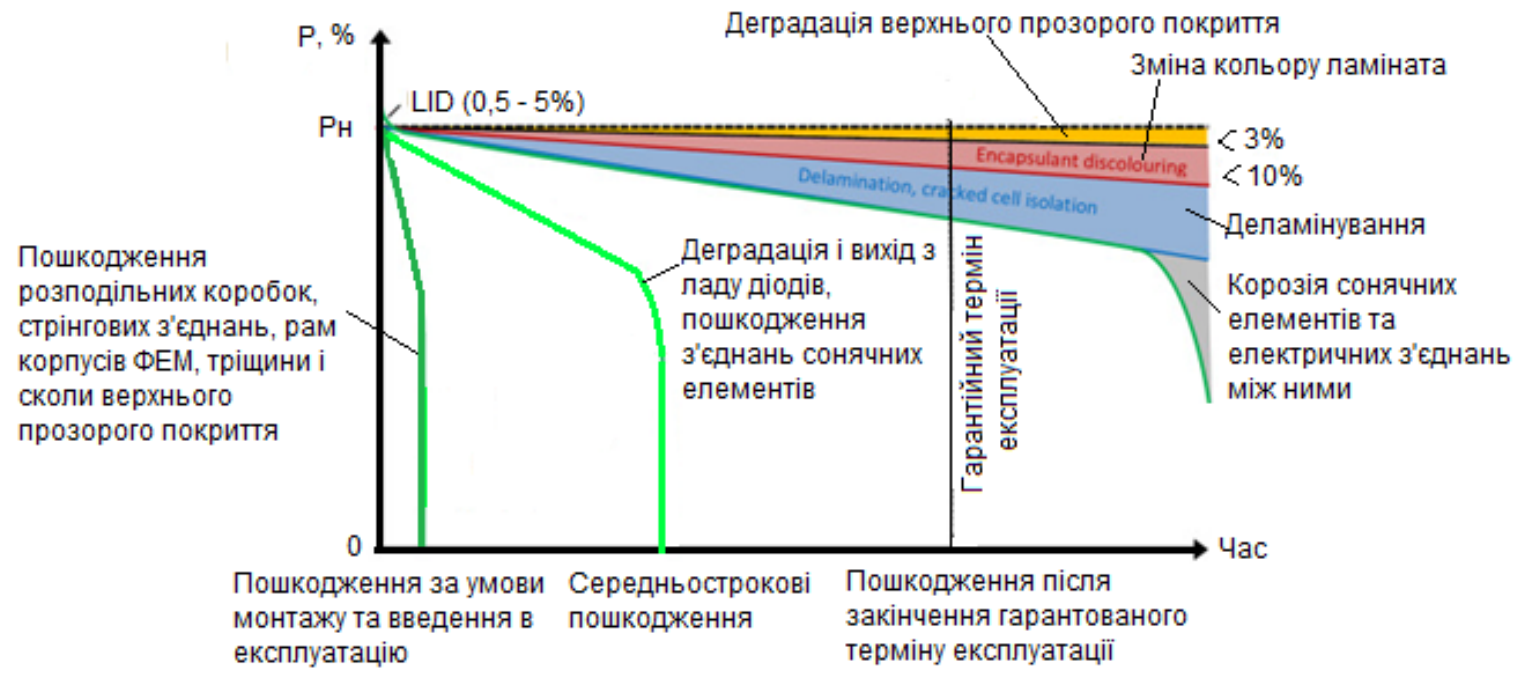

Рис. 2. Деградація складових частин фотоелектричного модуля в часі

Fig. 2.Degradation of photovoltaic module components in time 
Процеси деградації впродовж усього терміну експлуатації відбуваються і в напівпровідникових матеріалах сонячних елементів ФЕМ. Ці негативні зміни зазвичай мають нелінійну залежність у часі. Вони пов'язані також із зовнішніми чинниками кліматичного характеру. Швидкість деградації фотоелектричних модулів може бути представлена виразом Ареніуса [7]:

$$
D \propto \exp \left(-\frac{E_{a}}{k T}\right),
$$

де $E_{a}$ - енергія активізації в напівпровідниках (Ев); $k$ - константа Больцмана; $T$ - температура (К).

До цього можна додати модель деградації [10]:

$$
D t=1-\exp -b \cdot t^{a},
$$

де $b$ i $a$ - параметри конкретного типу деградації; $t$ - термін експлуатації ФЕС.

За статистикою залежно від терміну експлуатації ФЕС основні відмови та виходи 3 ладу сонячних модулів згідно [2] розподіляються на три групи (див. рис. 2).

До першої групи належать первинні пошкодження, які виникають вже під час монтажу це пошкодження розподільних коробок та їх контактів, пошкодження стрінгових з'єднань, тріщини на верхньому прозорому покритті, пошкодження рам корпусу модуля тощо.

Примітка. Стрінг - електричний контур, який складається з послідовно з'єднаних ФЕМ [1].

До другої групи належать пошкодження й виходи з ладу так званого середнього віку - це вихід 3 ладу байпасних i блокувальних діодів, пошкодження електричних з'єднань між сонячними елементами внаслідок тривалих механічних навантажень тощо.

I до третьої групи умовно можна віднести пошкодження, які з'являються при тривалому терміні експлуатації ФЕМ внаслідок деградаційних процесів впродовж значного часу. Це часткова втрата прозорості верхнього покриття й ламінату, поступове відшарування ламінату від поверхонь сонячних елементів і верхнього прозорого покриття й утрата в зв'язку з цим герметичності, корозія сонячних елементів та електричних з’єднань між ними тощо.

Аналіз процесів деградації показує [3], що вони здебільшого залежать від:

1) особливостей матеріалів та структури фотоелектричних перетворювачів;

2) конструктивних особливостей модуля (матеріалу верхнього прозорого покриття, матеріалів i розмірів внутрішніх прокладок, матеріалу ламінату тощо);

3) додержання технології виконання ламінування й електричного ізолювання та якісного виконання цих процесів;

4) принципів побудови електричної схеми ФЕС (схеми заземлення, особливостей з'єднання фотоелектричних модулів між собою та 3 інверторами тощо);

5) особливостей кліматичних факторів у місцевості розміщення ФЕС (велика амплітуда коливання температури; наявність сольових туманів, підвищених вітрових навантажень, підвищеного рівня вологості тощо).

У статті пропонуються деякі шляхи розв'язання проблем деградації ФЕМ, які залежать від факторів, вказаних у вищенаведених пунктах.

Однією з важливих деталей перебігу процесів деградації модулів $є$ те, що це відбувається інтенсивніше за умов холостого ходу, ніж за умов короткого замикання [4]. А це означає, що вирішальним параметром щодо прискорення процесів деградації у ФЕМ, які відбуваються під дією струмів витоку, є величина напруги [6].

За результатами розгляду виходу 3 ладу ФЕМ та аналізу основних видів втрати ними нормальних умов функціонування на рис. 3, $a$ i $\sigma$ показано струми витоків та шляхи пробоїв за ними, які характерні для кристалічного й тонкоплівкового типів фотоелектричних модулів відповідно. А, як відомо, ці струми витоків та, відповідно, пробої в ФЕМ залежать від величини напруги між сонячними елементами всередині модулів i заземленим каркасом, тобто зі збільшенням напруги на модулях, які належать до одного стрінга, зростає вірогідність появи тих чи інших струмів витоків і пробоїв, які призводять до виходу $з$ ладу ФЕМ. 


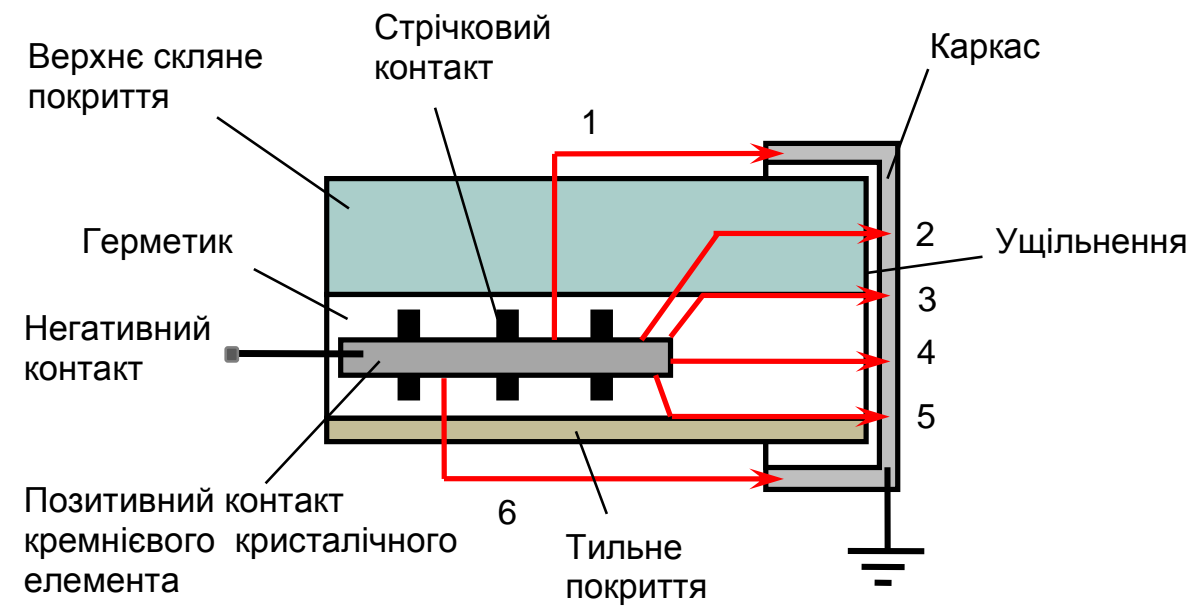

$a$

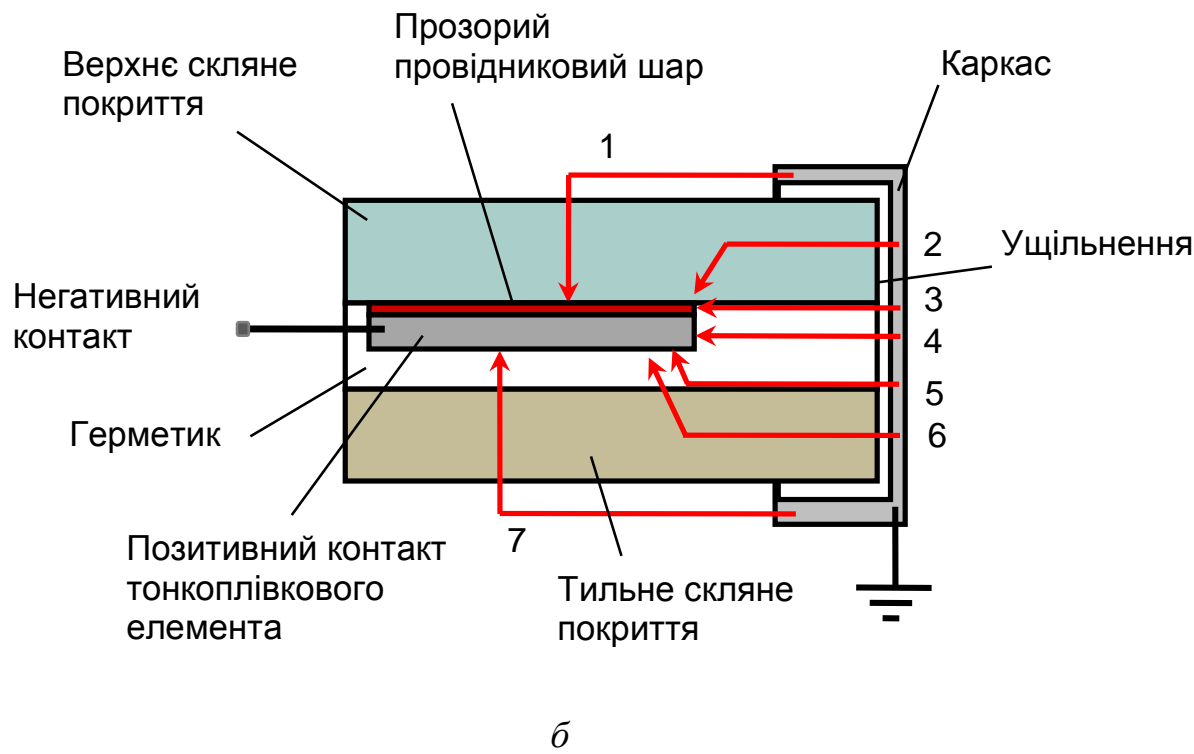

Рис. 3. Струми витоків та шляхи пробоїв у фотоелектричних модулях: $a$ - у кристалічних, якщо напруга на сонячних елементах вище потенціалу заземлення; $\sigma$ - у тонкоплівкових, якщо напруга на сонячних елементах нижче потенціалу заземлення

Fig. 3. Leakage currents and breakdown paths in photovoltaic modules: $a$-in crystalline ones, if the voltage on the solar cells is higher than the grounding potential; $b$-in thin-film, if the voltage on the solar cells is below the grounding potential

Аналізуючи рис. 3, $a$ і 6 , можна зробити висновок, що струми витоків у модулях залежать на лише від якості покриття й матеріалу ламінату, а й від опору антивідбивального покриття, нанесеного на поверхню сонячних елементів, опору матеріалу ущільнення та опору матеріалу тильного покриття.

Увагу до електрохімічної деградації у ФЕМ, пов'язаної 3 напругою (Potential Induced Degradation - PID), як до однієї з найважливіших складових загального процесу деградації [4] було привернуто ще в 1978 році. Ефект був описаний як міграція іонів $\mathrm{Na}^{+}$зі скла верхнього покриття ФЕМ через прозорий герметик, антивідбивальне покриття ( $\mathrm{SiNx}$ ) на поверхні елемента модуля, на заземлення. Міграція іонів керована струмом витоку в елементі. Значення цих струмів витоку зазвичай вимірюється в мкА і залежить від властивостей матеріалу, стану поверхні, включаючи вологість і температуру модуля, а також подану напругу [6]. 
Розглянемо у спрощеному варіанті традиційну електричну схему мережевих ФЕС (рис. 4). Тут зображено окремий стрінг послідовно з'єднаних ФЕМ та інвертор (не показано підвищувальний трансформатор, розрядники, вимикачі та інше обладнання, яке на генерування електричного струму фотоелектричними модулями та їх деградацію практично не впливає). Нижче на цьому рисунку також показана діаграма зростання напруги впродовж стрінга відносно заземлення всіх ФЕМ, що входять до складу стрінга.

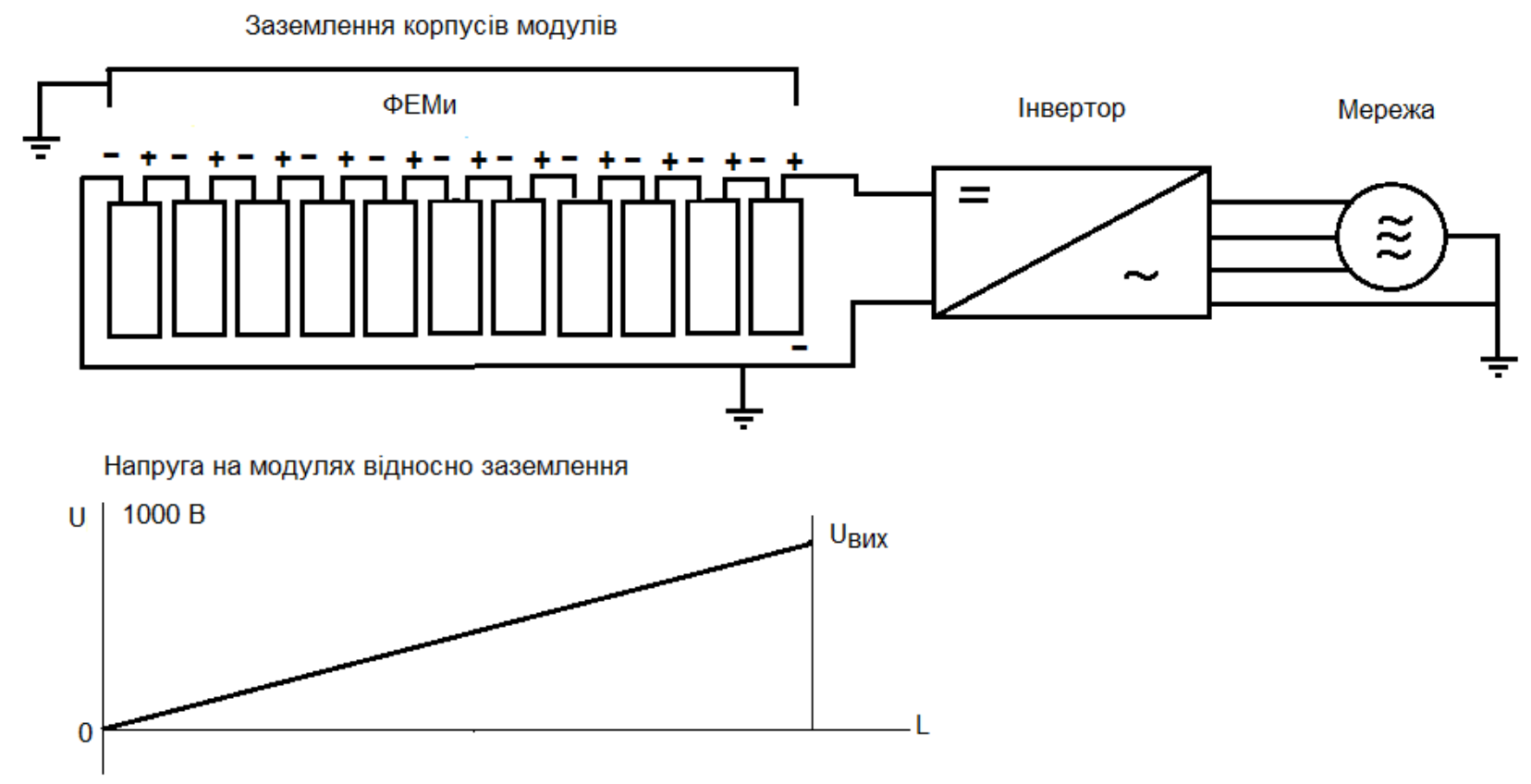

Рис.4. Спрощена традиційна електрична схема стрінга ФЕС

Fig. 4. Simplified traditional electrical circuit of PVP string

Як бачимо 3 діаграми, величина напруги на стрінгу, яка зазвичай для потужних мережевих інверторів, що експлуатуються, становить близько 1000 В, 3 одного боку, гарантує ефективну роботу останніх, а з іншого - підвищує ймовірність збільшення струмів витоків і пробоїв y ФЕM.

Примітка 1. Ефективність перетворення електричної енергії інвертором зростає зі зростанням вхідної напруги на ньому.

Примітка 2. В останніх схемних рішеннях ФЕС $з$ метою зниження амплітуди напруги точку заземлення модулів на станціях почали виконувати посередині стрінга (а не в його кінці, як робиться зазвичай), але при цьому було також помічено, що здебільшого виходять 3 ладу модулі, напруга на яких нижче, ніж на заземленні. Інакше кажучи, чим нижче потенціал відносно заземлення, тим вище ймовірність пошкодження модуля PID.
Тому найважливішими завданнями обслугового персоналу ФЕС $\epsilon$ своєчасне виявлення за допомогою спеціального обладнання й усунення пошкоджень, спричинених деградацією, пов'язаною 3 високою напругою (PID). Пошкодження такого роду можуть бути частково полагоджені (на початковій стадії) шляхом поляризації, або вони можуть бути незворотними, якщо на ФЕМ вже має місце електрохімічна корозія. I чим довше це пошкодження не усувається, тим більше ймовірність того, що воно стане незворотним.

Нині вже існують технічні засоби для виявлення та усунення наслідків PID в модулях. Так, для виявлення пошкоджених модулів використовується імітатор сонячного випромінювання в режимі спалаху 3 регульованою по потужністю електролюмінісцентна камера високої роздільної здатності (EL). Для своєчасного відновлення 
модулів як приклад можна навести використання приладу SMA PV Offset Box з робочою напругою від 300 до 600 В і струмом до 2 мА. Цей прилад застосовується в нічний час 3 метою нейтралізації та сповільнення поляризації й усунення наслідків PID [8].

На жаль, більшість власників та експлуатаційників ФЕС в Україні недостатньо інформовані щодо наслідків PID в модулях і не мають спеціального порівняно дорогого обладнання для виявлення та усунення проблем, вказаних вище.

Загалом деградація фотоелектричних модулів у часі оцінюється шляхом вимірювання та порівняння потужності. Інакше кажучи, деградація ФЕМ - це $\epsilon$ поступова втрата потужності впродовж експлуатації порівняно 3 початковою потужністю за однакових умов експлуатації [5].

Виходячи з міркувань, що зазвичай всі ФЕМ на станціях заземлені і з'єднані в стрінги, насамперед слід перевіряти модулі, які розташовані якнайдалі від точки заземлення або ближче до інверторів, де напруга стрінга максимальна. Найпростішим способом хоча б часткового відновлення розміщеного на ФЕС враженого PID модуля та сповільнення його подальшої деградації може бути видалення його зі стрінгу і тривале прогрівання (просушування).

Також можна практикувати перестановку пошкоджених PID модулів, розташованих у кінці стрінга (де порівняно висока напруга), і будь-яких модулів, не пошкоджених PID, які розташовані на початку цього ж стрінга i мають відносно невисоку напругу, але це бажано робити також після тривалого прогрівання пошкоджених модулів, як вказано вище.

Особливо часто поява струмів витоків i пробоїв у ФЕМ відбувається при низькій якості ламінування (гідроізоляції), частковій або повній втраті останньої та за умов високого рівня вологості й дії низьких (мінусових) температур.

Отже, зниження напруги на ФЕМ може суттєво зменшити струми витоків і в такий спосіб подовжити термін їх експлуатації.

Цього можна досягти, наприклад, шляхом заміни послідовного з'єднання ФЕМ у стрінзі на паралельне (або комбіноване) та введенням в електричну схему фотоелектричної станції DCDC перетворювача, який сприйматиме певний діапазон напруги й підвищуватиме постійну напругу до величини, необхідної для забезпечення ефективної роботи інвертора. Спрощене зображення електричної схеми стрінга ФЕС, що пропонується, представлено на рис. 5.

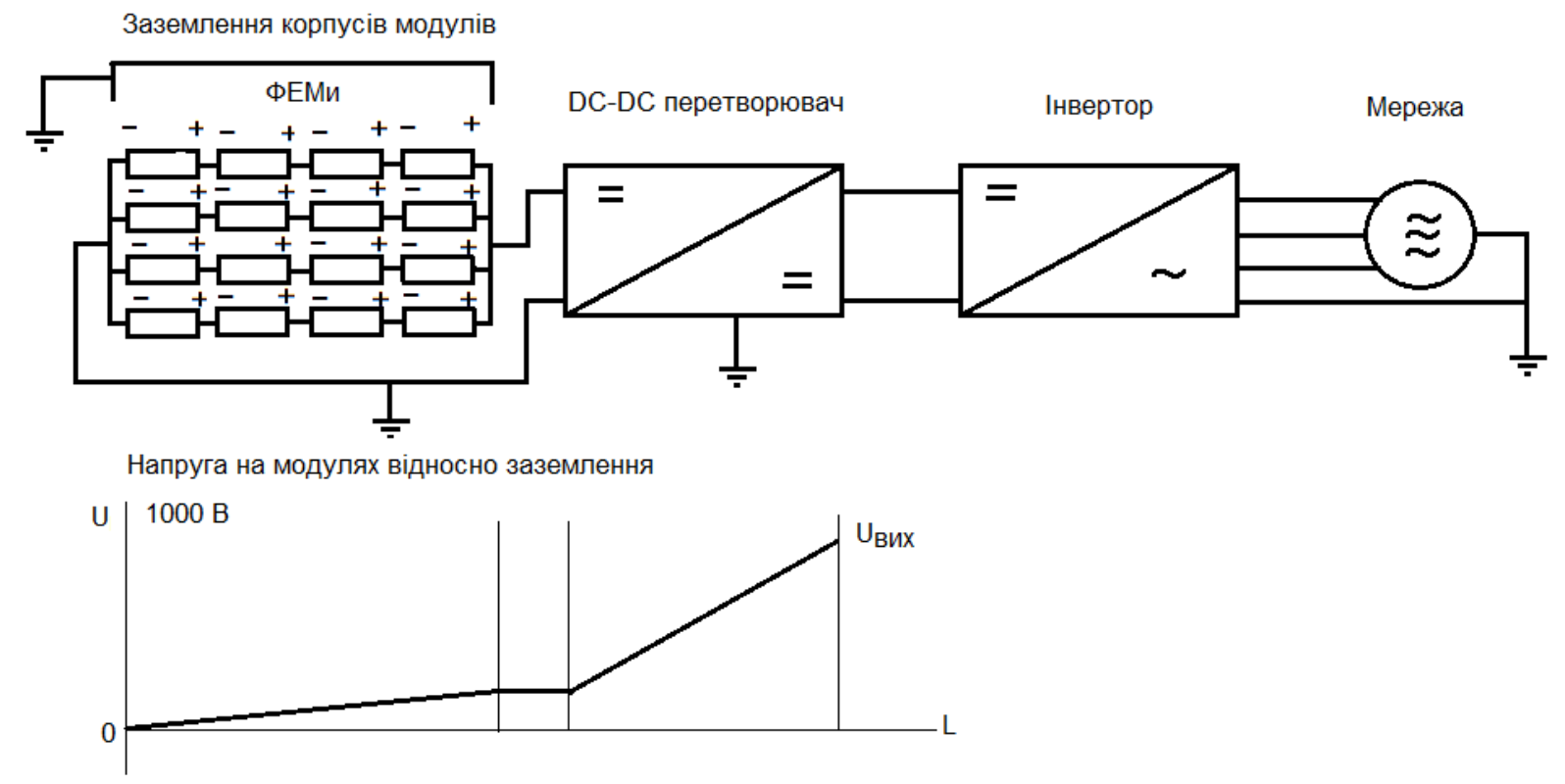

Рис. 5. Спрощена електрична схема стрінга ФЕС

Fig. 5. Simplified electrical diagram of the PVP string 
Як бачимо $з$ діаграми, зображеної на рис. 6 , величина напруги на ФЕМ при такому варіанті з'єднання буде значно меншою і, відповідно, внутрішні процеси деградації ФЕМ, що відбуваються за умови дії високої напруги, суттєво сповільняться і термін надійної безаварійної та ефективної експлуатації модулів зросте.

Ще один із шляхів зменшення деградації сонячних елементів у часі - більш активне й широке застосування замість звичайних ФЕМ комбінованих фотоелектричних модулів (КФЕМ) у комбінації 3 використанням DC-DC перетворювачів. Це дозволить суттєво знизити на сонячних елементах не тільки амплітуду коливань такого важливого параметра, як температура, а й зменшить вплив циклічності. Так, в літній період експлуатації КФЕМ його сонячні елементи вдень охолоджуються за рахунок відбору тепла теплоносієм, що циркулює в колекторі, а в зимовий - у разі необхідності вони можуть за низьких температур підігріватися. А амплітуда i річна циклічність температурних коливань, як відмічено вище, достатньо активно впливають на відмови фотоелектричної системи - так зване співвідношення Коффіна - Менсона [9] - та на швидкість деградаційних процесів у ФЕМ (КФЕМ) у ламінаті, верхньому прозорому i тильному покриттях i, відповідно, на корозію сонячних елементів тощо.

Крім того, подовження терміну ефективної експлуатації ФЕМ можна досягти за рахунок зниження напруги в самому модулі шляхом заміни загальноприйнятої схеми з'єднання фотоелементів послідовно в ФЕМ на паралельне або послідовно-паралельне (комбіноване) з'єднання з уведенням до електричної схеми та конструкції модулів DC-DC перетворювачів.

Розглянемо теоретичне підгрунтя цієї пропозиції. Загальна провідність напівпровідника, обумовлена фоторезистивним ефектом, пояснюється формулою:

$$
\sigma=\sigma_{0}+\sigma_{p h},
$$

де $\sigma_{p h}$ - фотопровідність напівпровідника, а

$$
\sigma_{0}=e n_{0} \mu_{n}+p_{0} \mu_{p},
$$

тут $\mu_{n}$ та $\mu_{p}-$ рухливість носіїв (дірок та електронів); $n_{0}$ та $p_{0}$ - рівновісні концентрації електронів та дірок; $e-$ елементарний електричний заряд, що становить $1,610^{-19}$ Кл.

Провідність $€$ величиною, зворотною до опору, тому зі зростанням провідності за умов сонячного випромінювання загальний опір ФЕМ спадатиме порівняно з неосвітленим його станом, а в разі паралельного з'єднання сонячних елементів між собою цей ефект тільки посилюється.

Тому паралельне з'єднання сонячних елементів (особливо це стосується елементів 3 кремнію, які сьогодні складають близько $80 \%$ всього ринку сонячних елементів), приведе до зниження загального внутрішнього опору, а отже, до збільшення робочого струму фотоелектричного модуля при одночасному зниженні напруги в ньому. Подальше підвищення напруги вважається доцільним перекласти на DC-DC перетворювачi, ККД яких на сьогоднішній день складає більше 90 \% і які у разі пошкодження можуть дуже легко замінюватися. DC-DC перетворювачі, враховуючи їх малі розміри, можна розмістити в розподільних коробках модулів.

Крім того, паралельне 3'єднання сонячних елементів між собою у ФЕМ не тільки знизить напругу між потенціалом ФЕМ та заземленням всередині модуля і зменшить кількість байпасних діодів, а й підвищить ефективність функціонування ФЕМ за умов часткового затінення останнього (сторонніми предметами, сніговим покривом, забрудненням тощо).

Висновки. Пропоновані зміни електричної схеми ФЕС або ФЕМ та інші конструктивнотехнологічні зміни, що приводять до зниження напруги на модулі, дадуть змогу:

1. Значно знизити швидкість деградаційних процесів у модулях, а значить, довше підтримувати заявлену ефективність та збільшити термін їх експлуатації.

2. Суттєво скоротити кількість байпасних діодів у модулі, призначених для розв'язання 
проблем із затіненням, та знизити при цьому швидкості деградаційних процесів у них.

Такі зміни потребуватимуть додаткового введення в стрінг ФЕС або в сам ФЕМ модуль підвищувальних DC-DC перетворювачів.

1. Пундєв В.О., Суржик Т.В., Шевчук В.І., Шейко I.O., Яиенко B.B. ДСТУ 7503:2014 Геліоенергетика. Станції фотоелектричні. Терміни та визначення понять. К.: Держспоживстандарт України. 2015. 44 c.

2. Köntges M., Kurts S. et al. Review of failures of PV modules. Report IEA-PVPS T13-01:2014.

3. Andorka F. UL White Paper: Getting More Reliability in PV Installations. July 16. 2014.

4. Jordan D.C., Kurts S. PV degradation rates - an analitical review. NREL. 2012.

5. Ndiaye A., Charki A. at al. Degradations of silicon photovoltaic modules: A literature review. July 8. 2013.

6. Hacke P., Terwilliger K., Smith R., Glick S., Pankow J., Kempe M., Bennett S.K.I., Kloos M. System voltage potential-induced degradation mechanisms in PV modules and methods for test. Proc. 37th PVSC. (Seattle, Washington, USA 2011). Pp. 814-820.

7. Kurtz S. Evaluation of high temperature exposure of rackmounted photovoltaic modules IEEE Photovoltaic Specialists Conference Philadelphia. Pennsylvania June 712. 2009

8. Pingel S. et al. Recovery methods for modules affected by potential induced degradation (PID).

9. Escobar L.A., Meeker W.Q. A Review of Accelerated Test Models. 2006. Vol. 21. № 4. 12 p.

10. Pan R., Kuitche J., Tamizhmani G. Degradation analysis of solarphotovoltaic modules: Influence of environmental factor. In: Proc. Annual Reliability and Maintainability Symposium. 2011.

\section{REFERENCES}

1. Pundev V.O., Surjyk T.V., Shevchuk V.I., Sheyko I.O., Yacenko V.V. ДSTУ 7503:2014 Gelioenergetika. Stancsyi fotoelektrychni. Terminy ta vyznachennya ponyat. [Solar energy. Photovoltaic stations. Terms and definitions]. Entered 01.01.2015. K. Derzhspozhyvstandart of Ukraine. 2015. 44 p.

[in Ukrainian].

3. Köntges M., Kurts $S$ et al. Review of failures of PV modules. Report IEA-PVPS T13-01:2014.

[in English].

3. Andorka F. UL White Paper: Getting More Reliability in PV Installations. July 16. 2014. [in English].

4. Jordan D.C., Kurts S. PV degradation rates - an analitical review. NREL. 2012. [in English].

5. Ndiaye A., Charki A. and other. Degradations of silicon photovoltaic modules: A literature review. July 8. 2013. [in English].

6. Hacke P., Terwilliger K., Smith R., Glick S., Pankow J., Kempe M., Bennett S.K.I., Kloos M. System voltage potential-induced degradation mechanisms in PV modules and methods for test. Proc. 37th PVSC. (Seattle, Washington, USA 2011). Pp. 814-820. [in English].

7. Kurtz S. Evaluation of high temperature exposure of rackmounted photovoltaic modules IEEE Photovoltaic Specialists Conference Philadelphia. Pennsylvania June $7-$ 12. 2009. [in English].

8. Pingel S. et al. Recovery methods for modules affected by potential induced degradation (PID). [in English].

9. Escobar L.A., Meeker W.Q. A Review of Accelerated Test Models. 2006. Vol. 21. No. 4. 12 p. [in English].

10. Pan R., Kuitche J., Tamizhmani G. Degradation analysis of solarphotovoltaic modules: Influence of environmental factor. In: Proc. Annual Reliability and Maintainability Symposium. 2011. [in English].

Стаття надійшла до редакції 16.02.21 Остаточна версія 15.06.21 